\title{
Uterine and ovarian countercurrent pathways in the control of ovarian function in the pig
}

\author{
T. Krzymowski, J. Kotwica and S. Stefanczyk-Krzymowska \\ Department of Reproductive Endocrinology, Centre for Agrotechnology and Veterinary Sciences, \\ 10-718 Olsztyn. Poland
}

Keywords: counter current transfer; ovary; oviduct; uterus; pig

\section{Introduction}

Countercurrent transfer of heat, respiratory gases, minerals and metabolites has been known for many years to be a fundamental regulatory mechanism of some physiological processes. In sea mammals, wading birds and fishes living in polar seas countercurrent systems in the limbs, flippers or tail vessels protect the organism against heat loss (Schmidt-Nielsen, 1981). In most mammals countercurrent heat exchange between the arteries supplying the brain and veins carrying the blood away from the nasal area and head skin forms the so-called brain cooling system, which protects the brain against overheating (Baker, 1979). The countercurrent transfer of minerals and metabolites in the kidney is a well-known system regulating the osmolarity and concentration of urine (Lassen \& Longley, 1961). Countercurrent transfers in the blood vessels of the intestinal villi take part in the absorption processes (Lundgren, 1967). The pampiniform plexus in the boar participates in a heat-exchange countercurrent, thus decreasing the temperature of the testes (Waites \& Moule, 1961), as well as in local transfer of testosterone (Free et al., 1973; Ginther et al., 1974; Einer-Jensen \& Waites, 1977). Studies on the influence of hysterectomy on the function of the corpus luteum in different species, made in the 1930-1970s, suggested the existence of a local transfer of a luteolytic substance from the uterus to the ovary. These suggestions have been confirmed by detailed and elegant anatomical papers of the vascular anatomy of the uterus, ovary and oviduct in mares (Ginther et al., 1972), cows (Ginther \& Del Campo, 1974), ewes (Ginther et al., 1973; Del Campo \& Ginther, 1973), sows (Del Campo \& Ginther, 1973) and laboratory animals (Del Campo \& Ginther, 1972). Ginther (1974) suggested that there was a local transfer of a luteolytic substance from the uterus to the ovary. The experiments of McCracken $e t a l$. (1972) on sheep were critical for understanding the mechanism of transfer of prostaglandins. Using radioactive prostaglandin they proved for the first time the existence of the local transfer of prostaglandin from the utero-ovarian vein to the ovarian artery. Moreover, the countercurrent transfer of radioactive inert gases was demonstrated in laboratory animals (Einer-Jensen, 1974), of progesterone in sheep (McCracken \& Einer-Jensen, 1976; Einer-Jensen \& McCracken, 1981; Walsh et al., 1979) and pigs (Krzymowski et al., 198 lb; Kotwica et al., 1981), of testosterone in pigs (Krzymowski et al., 1981 a; Krzymowski et al., 1981b) and cows (Kotwica et al., 1982), of oestradiol in pigs (Krzymowski et al., 198 lb) and cows (Krzymowski et al., 1981/1982; Koziorowski et al., 1988), of relaxin and thyroxin in ewes (Schramm et al., 1986a), and of oxytocin in sheep (Schramm et al., 1986b) and cows (Koziorowski et al., 1989).

The morphological adaptation of the walls of adjacent arterial and venous vessels (Lee \& O'Shea, 1975; Doboszyńska et al., 1980) and the relationship between countercurrent efficiency and the size of hormone molecules (McCracken et al., 1984) have been investigated in the context of the countercurrent mechanism. Kotwica (1980) suggested that the lymph and lymphatic vessels in sows participated in prostaglandin transfer in the area of the mesovarium. Heap et al. (1985) 
demonstrated that PGF-2 $\alpha$ transfer from the uterine lymph into the ovarian vasculature in sheep was potentially as great as that from the uterine venous blood.

Einer-Jensen $(1984,1988)$ suggested a relationship between the countercurrent transfer of hormones and hormones binding to plasma proteins. As far as is known, the pool of free steroids in the blood plasma is maintained in equilibrium with the pool of carrier-bound hormones, with only 1$2 \%$ of steroid hormones being in the unbound form in the arterial blood. According to EinerJensen $(1984,1988)$ the local transfer of free hormone from the veins and lymphatic vessels to the artery, even at a low efficiency of countercurrent exchange, can considerably multiply the concentration of free hormone in arterial blood that is able to interact with the receptor. Moreover, it was suggested that the less polar (ketonic) member of each steroid pair was transferred more efficiently than its hydroxyl counterpart. This may be due to its greater solubility in the membrane lipids of the cells in the interposing vessel walls (McCracken et al., 1984).

\section{Role of the broad ligament of the uterus in the countercurrent transfer of hormones}

\section{Mesovarium}

In sows the ovarian artery is subdivided into several basic branches in the mesovarium area. After division, one of them reaches the mesosalpinx and oviduct and provides the mesovarian muscular layer with numerous tiny ramifications. Two or three middle branches form many loops on the surface of and near the ovarian vein, and some of them anastomose with the uterine artery. The ramifications of convoluted branches go deep into the vessel plexus and surrounding muscular layer. All the vessels are covered with a muscular layer which is especially well developed in the ovarian area. Lymph drains from the ovary through numerous tiny lymphatic vessels situated immediately under the perimetrium covering the muscles. This network of lymphatic vessels is drained in turn by large valved vessels deep in the convoluted arterial branches (T. Krzymowski, unpublished observations).

The rhythmic contractions of the muscular layer of the mesovarium results in changes of the venous blood and lymph flow (T. Krzymowski, unpublished observations). The muscular layer of the broad ligament is supplied with the arterial blood that passes through the fine, short arterial ramifications that leave the branches of the ovarian artery at right angles. These arterial ramifications penetrate the muscular layer of the mesovarium and create a capillary bed. The blood from the muscular layer returns through fine, short veins which, reaching the branches of the ovarian artery, redivide on the arterial surface or pass by to connect with the venous network covering the arteries (Fig. 1).

The origin of the network covering the branches of the ovarian arteries is still not clear. Lee \& O'Shea (1975) suggested that in ewes this venous network was supplied with uterine blood. In sows a fine venous network covering the walls of the ovarian artery branches has been described in detail (Figs $2 \mathrm{a}, \mathrm{b}$ ). It was functionally associated with countercurrent transfer of steroid hormones and prostaglandins in the area of the mesovarium (Krzymowski et al., 1982a; Kotwica et al., 1982/ 1983). The venous network was found to twine around the artery covering more than half of the surface of the ovarian artery branches (Fig. 2b). It is only loosely associated with the surface of the adjacent arterial walis and can be easily removed.

Spontaneous or mechanically stimulated contractions of a section of the convoluted branches of the ovarian artery were studied during in-situ experiments which restricted blood flow through the venous network covering the contracting section ( $T$. Krzymowski, unpublished observations). The nervous and hormonal regulation of blood flow through the convoluted branches of the ovarian artery, as well as through the venous network covering the branches, may therefore be an important component of the countercurrent mechanism of the mesovarium area.

In 1976, McCracken \& Einer-Jensen showed for the first time the possibility of progesterone countercurrent transfer in the mesovarium in ewes. In sows, tritiated testosterone introduced into 


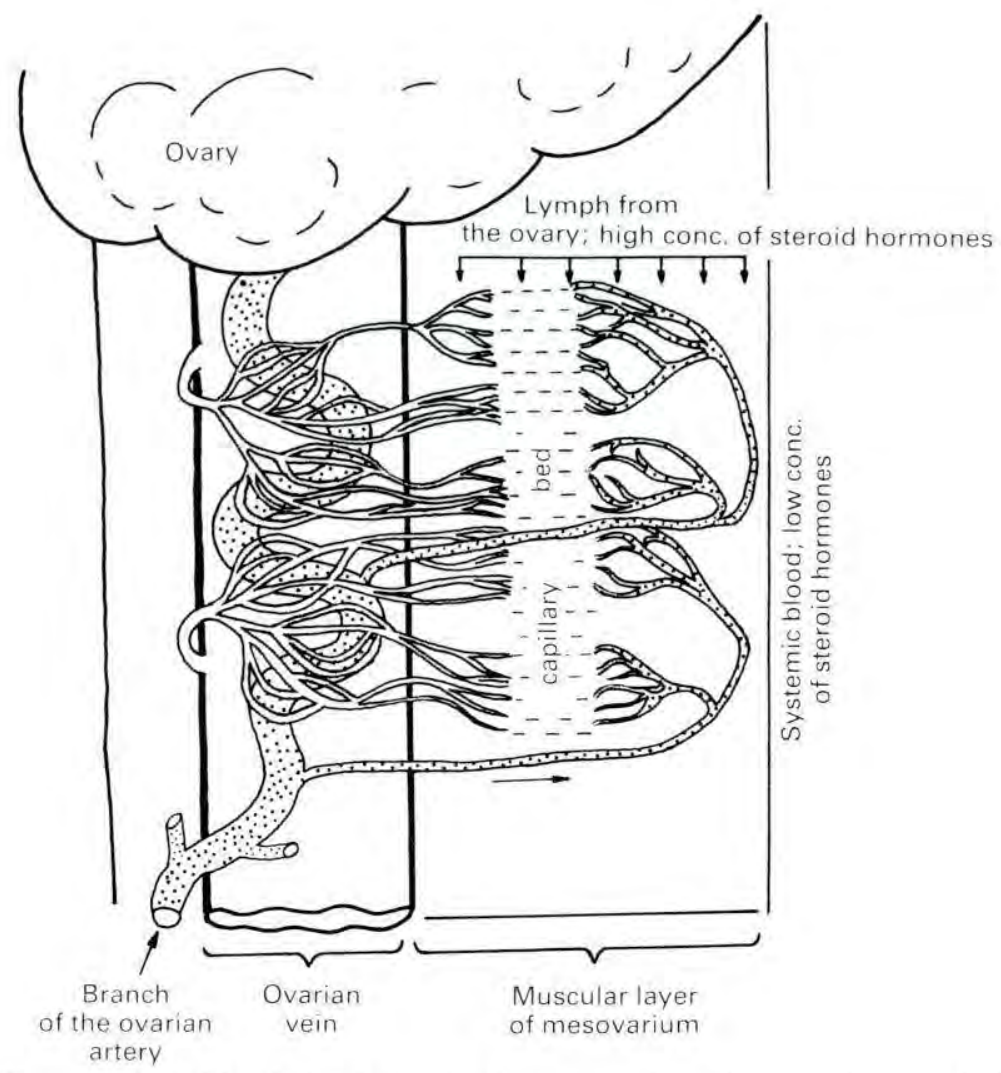

Fig. 1. Diagram of the blood circulation in the mesovarium showing the morphological conditions for two steps in the transfer of steroid hormones. First step: from the lymph (high steroid concentration) into the capillaries of the muscular layer supplied with the systemic blood (low steroids concentration). Second step: from the venous network (high concentration) covering the branches of the ovarian artery into the arterial blood (low concentration). (Adapted from Krzymowski et al., 1982b).

the ovarian vein was found in high concentrations in the ovarian artery (Krzymowski et al., 1979). Many experiments on the ovary isolated with the mesovarium and supplied by the autologous blood proved that testosterone, oestradiol and progesterone were transferred from the ovarian vein to the artery in the mesovarium area (Krzymowski et al., 1981a, b, 1982a, b; Kotwica et al., 1981).

The dynamics of steroid uptake and retention in the mesovarium after infusion of $\left[{ }^{3} \mathrm{H}\right]$ testosterone into the ovarian vein was studied by Stefanczyk (1984). The capacity for total binding of $\left[{ }^{3} \mathrm{H}\right]$ testosterone in the mesovarium was considerably higher than in other parts of the broad ligament. High values of $\left[{ }^{3} \mathrm{H}\right]$ testosterone in the cytosol were mostly bound by albumin and $\alpha_{1}$ globulin, but the absence of $\left[{ }^{3} \mathrm{H}\right]$ testosterone in the nuclear fraction suggested that binding was not receptor mediated (Stefanczyk, 1984).

The transfer of testosterone, oestradiol and progesterone from the venous effluent to the ovarian artery in sows turned attention to the role of lymph in this area. The concentration of steroids in the ovarian lymphatic outflow in sows has not been investigated under physiological conditions in vivo. During experiments on the ovary isolated with the ovarian pedicle, the steroid concentrations were higher in the lymph and interstitial fluid than in the venous blood (Kotwica et al., 1981). In ewes, chronic cannulation of the utero-ovarian lymph ducts ipsilateral to the ovary bearing the corpus luteum showed that the concentration of progesterone in lymph was 

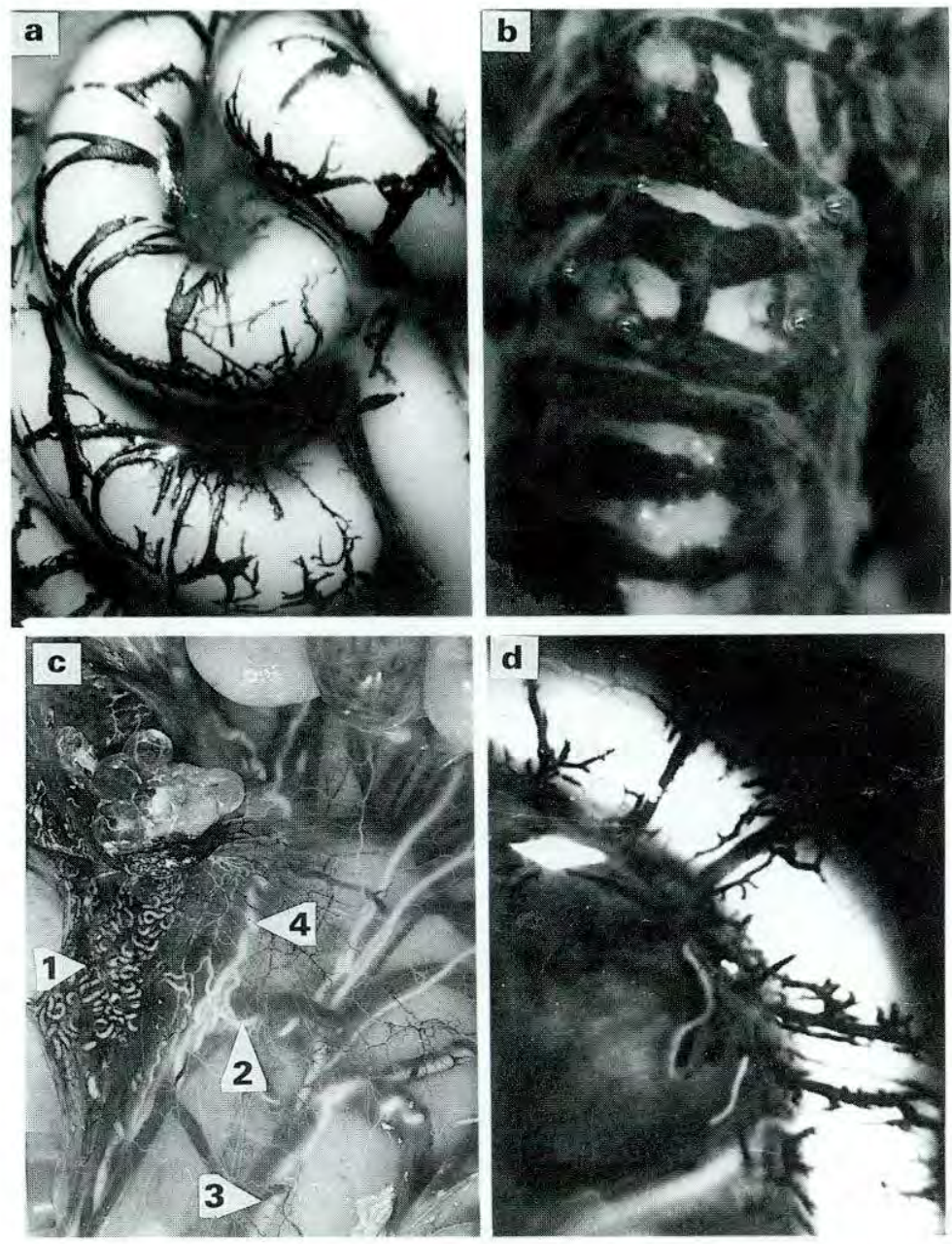

Fig. 2. Blood vessels in the mesovarium of the pig. (a) The ovarian arterial branches (filled with white latex) covered by the venous network (filled with black latex). The venous network twines around the artery. (b) Magnified picture of a single branch (white) and of the venous network (black) covering a major part of the arterial surface. (c) The vascularization of the mesometrium. The ovarian artery (filled with white latex) divides and forms many convoluted branches (1) reaching the ovary among the venous vessels (filled with black latex). An anastomosis (2) between the branches of the ovarian and uterine artery (3) is visible. One of the ovarian arterial branches (4) directly supplies that part of the uterine horn proximal to the ovary. (d) The branch of the uterine artery from the mesometrium. The artery (filled with white latex) is entwined by the venous network (filled with black latex). (a: photographed by C. Nagiec; b, c, d: photographed by A. Penkowski).

10-1000-fold higher than in jugular vein plasma (Staples et al., 1982). Lymph with high concentrations of steroid hormones flows through the superficial lymphatic vessels in the mesovarium area and meets systemic arterial blood supplying this area with much lower concentrations of steroids (Fig. 1). The directions of the flow are opposite. Countercurrent transfer from lymph to blood takes place mainly in the area of the capillary bed (first step). Consequently, the venous blood leaving this area transports considerably higher concentrations of steroids from the mesovarial muscles to the ovarian vascular pedicle. As previously described, venous vessels redivide on the surface of the 
ovarian artery branches. The blood flowing through the venous network covering the branches of the ovarian artery thus delivers the hormones to the arterial blood according to the concentration gradient (second step). Thus hormone-enriched arterial blood supplies the ovary, oviduct and the tip of the uterine horn.

Such a local concentrating mechanism, increasing hormones in the arterial blood, may in part regulate the blood flow through the vascular system of supplied tissues. The rise of oestrogen concentrations in the ovarian artery as the result of countercurrent transfer may induce local hydroxylation of the aromatic ring in oestradiol and the formation of catecholoestrogens which contain two instead of one phenolic hydroxyl group on the aromatic ring. Like catecholamines, catecholoestrogens can block the $\mathrm{Ca}^{2+}$ channels in $\alpha$-adrenergic receptors in smooth muscle cells of the vessels and so block or change the function of the receptor. This leads to arterial vasodilatation and increases blood flow in the uterine artery (Ford, 1985). Moreover, the pattern of uterine blood flow to the non-pregnant pig uterus is negatively correlated $(r=-0.94)$ with the concentration of progesterone in the blood (Ford \& Christenson, 1979) and progesterone alters the function of the uterine or ovarian sympathetic nerves by changing the number and activity of $\alpha_{1}$-adrenergic receptors (Ford et al., 1984; Dynarowicz et al., 1988). The ratio of oestrogen to progesterone in the blood supplying the genital organs may affect both the ovarian as well as uterine blood flow. In sows the blood flow to the ovaries changes regularly during the oestrous cycle, being highest during the luteal phase and lowest during follicular phase (Magness et al., 1983). However, blood flow through the uterine artery is increased after systemic (Dickson et al., 1969) or intrauterine (Ford (t al., 1982) administration of oestradiol.

\section{Mesosalpinx}

The primary function of the oviduct and mesosalpinx is the collection and transport of eggs.

Like other arterial branches supplying the ovary, the branch of the ovarian artery supplying the mesosalpinx and oviduct forms many spirals. To discover whether this vascular system is able to affect the local transfer of steroid hormones into the ovary, special experimental models were adopted with isolated organs (Figs 3 \& 4).

On Days 14-17 of the oestrous cycle the isolated ovary with its ovarian pedicle was infused via the ovarian vein for $30 \mathrm{~min}$ with radioactive steroid hormones. Radioactivity was found in the blood taken from both the ovarian and the oviduct branches of the ovarian artery (Fig. 3). In subsequent experiments the mesosalpinx of an infused preparation (Preparation A) closely overlaid the other isolated ovary (Preparation B) placed nearby in a separate box and supplied with the arterial blood (Fig. 4). During the experiment $0.6 \%$ of $\left[{ }^{3} \mathrm{H}\right]$ testosterone infused into Preparation A was transferred through the mesosalpinx vasculature into the ovary and mesovarium of Preparation B (Krzymowski et al., 1982c). In a similar experiment, the ovary of Preparation B was enveloped by the mesosalpinx of Preparation A injected with $\left[{ }^{3} \mathrm{H}\right] \mathrm{PGF}-2 \alpha$ (Fig. 5) (Kotwica et al., $1982 / 1983)$. The labelled prostaglandin injected into the uterus was found in the venous effluent $(0.15 \%$ of the dose injected into Preparation $\mathrm{A})$, as well as in the ovarian pedicle tissue of Preparation B. This suggests a possible new route of PGF-2 $\alpha$ transfer from the uterus through the mesosalpinx into the corpus luteum of pigs (Kotwica et al., 1982/1983). The transfer of progesterone from the corpus luteum into the mesosalpinx vasculature has been shown (Adamowicz et al., 1989). Moreover, it was demonstrated that follicular hormones were transferred from the ovarian vein to the ovarian and utero-tubal arteries, thus providing a local means of regulating oviduct function and sperm transport (Hunter et al., 1983). Elevated concentrations of steroids and prostaglandins transferred in this way would permit incisive changes in the potency and contractile activity of the isthmus, thereby facilitating the periovulatory phase of sperm transport from the caudal portion of the oviduct to the site of fertilization (Hunter et al., 1983). These results indicate that the oviduct and part of the uterine horn proximal to the ovary could be supplied directly by a local pathway with hormones released from the ovary into the blood and transported through the anastomoses between the ovarian and uterine artery into the target organs. 


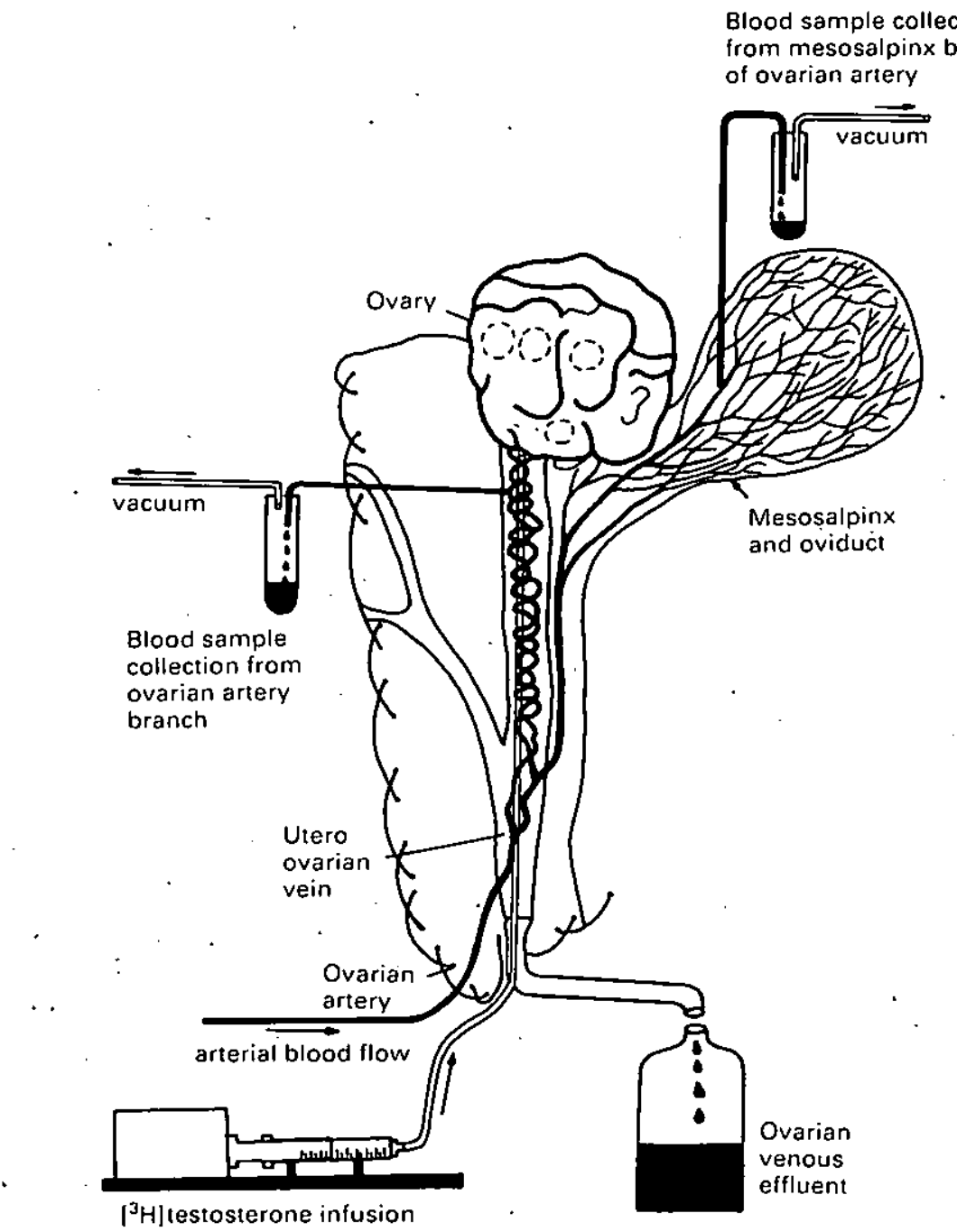

Fig. 3. Experimental design for studying the countercurrent transfer of $\left[{ }^{3} \mathrm{H}\right]$ testosterone from the ovarian vein into the blood of the mesosalpinx vasculature: $\left[{ }^{3} \mathrm{H}\right]$ Testosterone was infused via the tip of a cannula positioned in the ovarian vein $1-2 \mathrm{~cm}$ from the ovary. Blood samples were taken from the ovarian vein, the oviducal branches of the ovarian artery and from the cannulated ovarian vein. (Adapted from Krzymowski et al., 1982c).

\section{Mesometrium}

In the mesometrium the uterine veins cover and twist along the branches of the uterine artery (Ginther, 1974; Krzymowski et al., 1989). This results in a large area of close surface contact between the veins and arteries and favours a direct passage of substances between the two. A large part of the surface of the uterine artery branches is covered with a thin-walled venous mesh (Fig. 2d). After the injection of Evans' blue dye into the superficial layer of the myometrium, lymphatic vessels in the whole area of the mesometrium could be clearly observed. These observations showed that lymph drained from the uterus vessels through numerous valved vessels that lay parallel to the branches of the uterine artery, as well as in a superficial mesh of unvalved lymphatic vessels draining the mesometrium just under the perimetrium. Moreover, the fine thin-walled lymphatic vessels of the superficial mesh were connected with the valved vessels lying parallel with the branches of the 


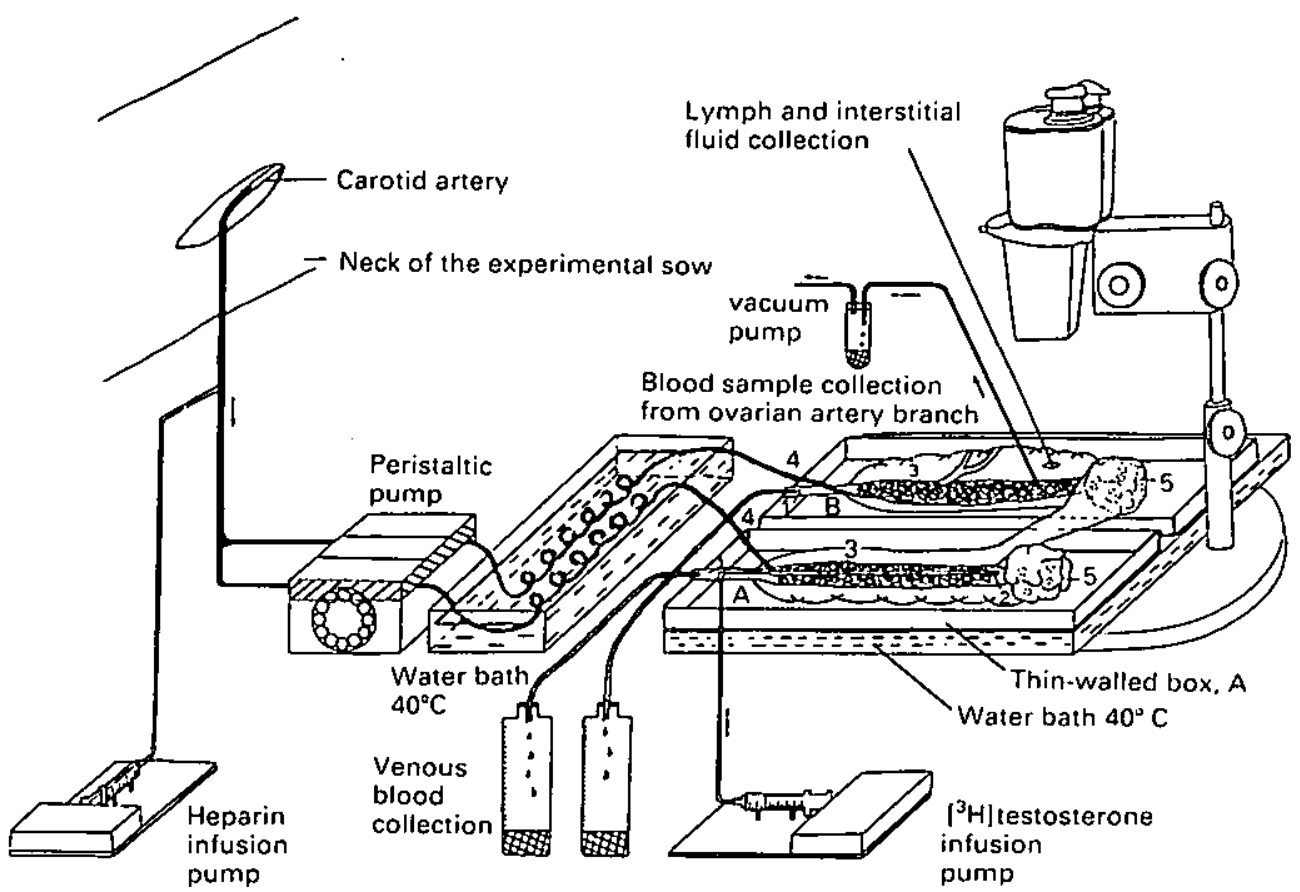

Fig. 4. Experimental design for studying $\left[{ }^{3} \mathrm{H}\right]$ testosterone transfer from the mesosalpinx vasculature into the ovary. $\left[{ }^{3} \mathrm{H}\right]$ testosterone was infused into the ovarian vein, $1-2 \mathrm{~cm}$ from the ovary of Preparation A. The mesosalpinx of Preparation A was placed on the surface of the ovary of Preparation B. Radioactivity was measured in blood and lymph samples taken from Preparation B. Preparations A and B were connected by the mesosalpinx only. 1, The ovarian vein; 2 , tip of the cannula for testosterone infusion; 3 , spirals of the ovarian arterial branches; 4 , cannula with arterial blood connected with the ovarian artery; 5 , the ovary; 6 , the mesosalpinx and oviduct of the infused Preparation A covering the ovary of Preparation B (Krzymowski et al., 1982c).

uterine artery (Krzymowski et al., 1986). Figure 6 illustrates the connections between the arterial, venous and lymphatic vessels along the mesometrium.

The infusion of $\left[{ }^{3} \mathrm{H}\right] \mathrm{PGF}-2 \alpha$ into the most superficial layer of the myometrium of an isolated uterus, injection of $\left[{ }^{3} \mathrm{H}\right] \mathrm{PGF}-2 \alpha$ into the lumen of an isolated uterine horn (supplied with autologous blood), and $\left[{ }^{3} \mathrm{H}\right] \mathrm{PGF}-2 \alpha$ infusion into the myometrium of an anaesthetized sow resulted in the presence of $\left[{ }^{3} \mathrm{H}\right] \mathrm{PGF}-2 \alpha$ in the blood taken from the uterine artery (Krzymowski et al., 1986). The mechanism of PGF-2 $\alpha$ countercurrent transfer from the venous and lymphatic effluent was active during the luteal phase of the oestrous cycle, but it was noticeably reduced on Days 13-17 of the cycle when luteal regression was taking place (Fig. 7). A significantly higher concentration of $\left[{ }^{3} \mathrm{H}\right] \mathrm{PGF}-2 \alpha$ in the uterine arterial plasma was found in pregnant (14-18 days of pregnancy), and in oestrogen-induced pseudopregnant sows (15-18 days of the oestrous cycle), than in the control group (13-17 days of the cycle) (Table 1).

In experiments in vivo (Koziorowski et al., 1988) tritiated prostaglandin was injected into the uterine lumen of sows on Day 18 of pregnancy. An increase in the level of radioactivity in blood taken from the branch of the uterine artery, compared to radioactivity in an equal volume of blood sampled simultaneously from the carotid artery, was presented as evidence for the existence of PGF- $2 \alpha$ back transfer in the area of the broad ligament vasculature. It was demonstrated that the concentration of $\left[{ }^{3} \mathrm{H}\right] \mathrm{PGF}-2 \alpha$ in uterine artery plasma was significantly higher than in carotid artery plasma $(P<0.001)$. Total radioactivity transferred back into the uterus with the arterial 


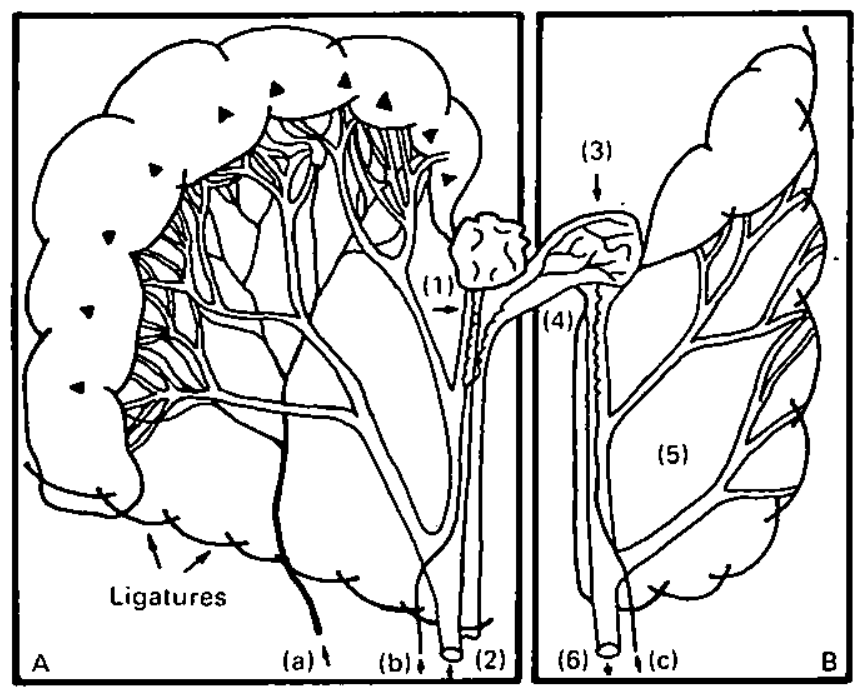

Fig. 5. Schematic diagram of the experimental design for studying $\left[{ }^{3} \mathrm{H}\right] \mathrm{PGF}-2 a$ transfer from the uterine horn into the ovary. $\left[{ }^{3} \mathrm{H}\right] \mathrm{PGF}-2 \alpha$ was injected into the musculature of Preparation A (black triangles). Arrows indicate the direction of the blood flow into the uterine artery (a) into the ovarian artery $(b, c)$ and from the utero-ovarian veins $(2,6)$. The mesosalpinx of Preparation A closely covered the surface of the ovary of Preparation B. Radioactivity was measured in the ovarian effluent $(1)$; the ovarian venous effluent $(2,6)$; the ovarian tissue $(3)$; the ovarian pedicle tissue (4); and in the lymph and interstitial fluid (5). (Adapted from Kotwica et al., 1982/1983).

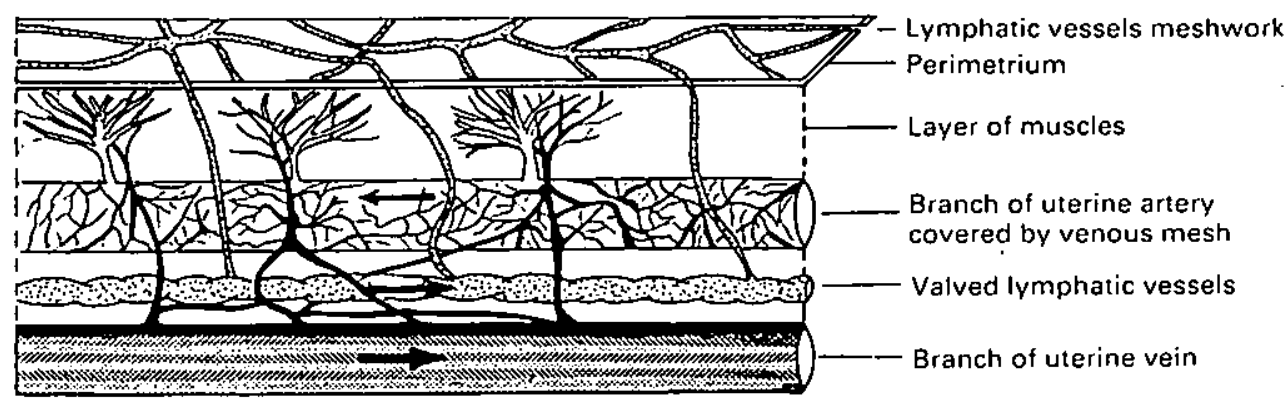

Fig. 6. Schematic diagram showing the general structure of the broad ligament and the connections observed between the lymphatic, venous and arterial vessels along the mesometrium. (Adapted from Krzymowski et al., 1986).

blood was calculated as $2 \%$ of the injected dose (Koziorowski et al., 1988). In experiments carried out in very similar conditions (S. Stefanczyk-Krzymowska, T. Krzymowski, N. Einer-Jensen, T. Kaminski \& J. Kotwica, unpublished), total radioactivity transferred back was calculated as $1.73 \%$ of total infused $\left[{ }^{3} \mathrm{H}\right] \mathrm{PGF}-2 \alpha$, while transfer efficiency was $11.6 \%$. No correlation was found between $\left[{ }^{3} \mathrm{H}\right] \mathrm{PGF}-2 \alpha$ concentration in the venous effluent and its simultaneous back transfer to the arterial blood, or between the distribution of the radioactive prostaglandin in the walls of the vessels and in the tissues of the mesometrium surrounding the vessels. Figure 8 indicates that the mechanism of PGF-2 $\alpha$ transfer in the area of the broad ligament vasculature is not based on simple diffusion through the vessels walls, but is strictly limited by the different abilities of the tissues to bind and concentrate prostaglandin (S. Stefanczyk-Krzymowska, T. Krzymowski, N. 


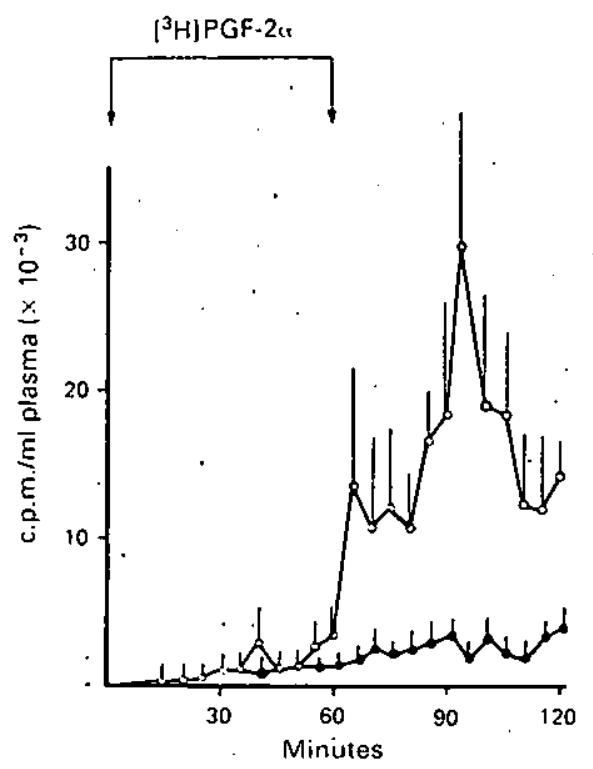

Fig. 7. Radioactivity (mean \pm s.e.m.) per $\mathrm{ml}$ of the blood taken from the branch of the uterine artery during and after infusion of $25 \mu \mathrm{Ci}\left(25 \times 10^{6}\right.$ c.p.m.) $\left[{ }^{3} \mathrm{H}\right] \mathrm{PGF}-2 \alpha$ into the superficial layer of the myometrium of sows on Days 2-12(O-O) $(\mathrm{N}=5)$ or Days 13-17 $(0-0)$ of the oestrous cycle $(\mathrm{N}=4)$. Significant differences $(P<0.01, P<0.05)$ were observed. during 80-120 min of the experiment. (From Krzymowski et al., 1986).

Table 1. Mean ( \pm s.e.m.) total radioactivity transferred from the broad ligament vasculature into the uterus with arterial blood during a $120-\mathrm{min}$ period after infusion of $7 \times 10^{7} \mathrm{c} . \mathrm{p} . \mathrm{m}$. of $\left[{ }^{3} \mathrm{H}\right] \mathrm{PGF}-2 \alpha$ into the myometrium (calculated from the amount of radioactivity in $1 \mathrm{ml}$ of blood plasma taken from the branch of the uterine artery and the total volume flowing ihrough the specimen

(from Krzymowski ei al., 1987)

\begin{tabular}{lccc}
\hline $\begin{array}{l}\text { Uterine horn isolated } \\
\text { from animals on: }\end{array}$ & $\begin{array}{c}\text { No. of } \\
\text { sows }\end{array}$ & c.p.m. $\left(\times 10^{6}\right)$ & $\begin{array}{c}\% \text { of infused } \\
{\left[{ }^{3} \mathrm{H}\right] \text { PGF-2a }}\end{array}$ \\
\hline $\begin{array}{l}\text { Days 15-18 of. } \\
\text { pseudopregnancy }\end{array}$ & 8 & $13.91 \pm 7.83^{*}$ & 19.8 \\
$\begin{array}{l}\text { Days 14-18 of } \\
\text { pregnancy }\end{array}$ & 8 & $4.20 \pm 0.53^{* *}$ & 6.0 \\
$\begin{array}{l}\text { Days 13-17 of the } \\
\text { oestrous cycle }\end{array}$ & 8 & $1.79 \pm 0.69$ & 2.4 \\
\hline
\end{tabular}

Significantly different from value for gilts on Days 13-17 of the oestrous cycle: ${ }^{*} P<0.05 ;{ }^{* *} P<0.001$.

Einer-Jensen, T. Kaminski \& J. Kotwica, unpublished). It was concluded that prostaglandin retention in the tissues of the reproductive organs created a temporary reservoir which may be gradually released. Such a mechanism in physiological conditions may reduce the peaks of PGF-2 $\alpha$ concentration observed in the venous blood by Frank et al. (1977) and by Hunter \& Poyser (1982), and may prevent luteal regression in early pregnancy (Krzymowski et al., 1987, 1989). In experiments with early pregnant sows (Day 18), $\left[{ }^{3} \mathrm{H}\right] \mathrm{PGF}-2 \alpha$ was circulated in the blood for $2 \mathrm{~h}$ at a concentration of $\sim 300$ d.p.m./ml plasma. After this time radioactivity was measured in the uterine tissues 
and uterine flushings (Table 2). The presence of $\left[{ }^{3} \mathrm{H}\right] \mathrm{PGF}-2 \alpha$ in the uterine tissues and in uterine flushings at a concentration exceeding the content of the arterial blood confirmed the capacity of the uterine tissue for binding, retention and removal of $\left[{ }^{3} \mathrm{H}\right] \mathrm{PGF}-2 \alpha$ into the uterine lumen. Bazer \& Thatcher (1977) suggested that PGF-2 $\alpha$ accumulation in the uterine lumen during early pregnancy was evidence for its exocrine secretion towards the uterine lumen. However, our unpublished results (S.. Stefanczyk-Krzymowska, T. Krzymowski, N. Einer-Jensen, T. Kominski \& J. Kotwica) indicate that the high PGF-2 $\alpha$ level found in the uterine lumen during early pregnancy (Thatcher et al., 1986) could also be a consequence of PGF-2 $\alpha$ uptake from the arterial blood supplying the uterus and removal into the uterine lumen. Labelled prostaglandin found in uterine flushings in concentrations many-fold higher than in the blood supplying the uterus (Table 2) supported this suggestion.

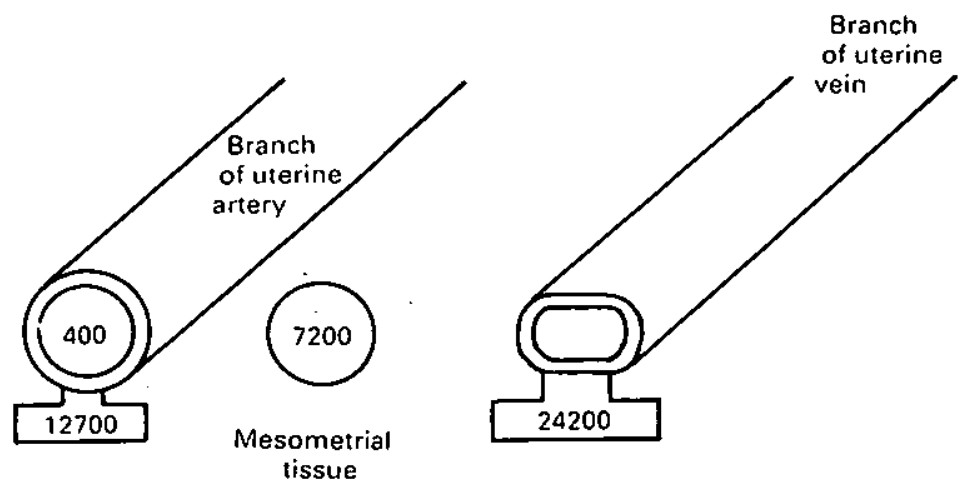

Fig. 8. The concentration of radioactive prostaglandin in the wall of the uterine arterial and verious branches and in the mesometrial tissues surrounding these vessels (d.p.m./g) $2 \mathrm{~h}$ after the injection of $10^{8} \mathrm{~d}$.p.m. of $\left[{ }^{3} \mathrm{H}\right] \mathrm{PGF}-2 \alpha$ into the uterine lumen. The mean concentration of $\left[{ }^{3} \mathrm{H}\right] \mathrm{PGF}-2 \alpha$ is also presented (d.p.m./ml of blood plasma) for the arterial blood taken during the $2 \mathrm{~h}$ of the experiment. The differences are significant, $P<0.01$.

Table 2. Mean concentrations of $\left[{ }^{3} \mathrm{H}\right] \mathrm{PGF}-2 \alpha$ in various tissues of sows $(\mathrm{N}=8) 2 \mathrm{~h}$ after injection of $\left[{ }^{3} \mathrm{H}\right]$ PGF- $2 \alpha\left(10^{8} \mathrm{dpm}\right)$ into the lumen of a scparated uterine horn

\begin{tabular}{lr}
\hline Conc. of $\left[^{3} \mathrm{H}\right] \mathrm{PGF}-2 \alpha$ & d.p.m. \\
\hline In arterial blood plasma supplying & \\
the uterus & $253-329$ \\
In the endometrium & 1730 \\
In the myometrium & 3800 \\
In $1 \mathrm{ml}$ uterine flushings & 1410 \\
In total uterine flushings $(100 \mathrm{~m} !)$ & 141000 \\
\hline
\end{tabular}

\section{Conclusions}

(1) The broad ligament (mesovarium, mesosalpinx and mesometrium) is not only a tissue supporting the arterial, venous and lymphatic vessels, as well as nerves, but is also an organ involved in the hormonal regulation of reproductive processes. 
(2) Countercurrent exchange of hormones in the area of the broad ligament vasculature takes place through two complementary processes:

(i) direct passage through the walls of two adjacent vessels according to the well-known mechanism of countercurrent heat exchange;

(ii) indirect, two-step passage. Steroid hormones and prostaglandins pass from the lymphatic vessels into the arterial blood supplying capillaries of the muscular layer of the broad ligament according to a concentration gradient (first step). Then, the blood flowing out from these capillaries transports locally high concentrations of hormones into the venous mesh covering the wall of the ovarian artery. Significant differences in hormone concentrations within these vessels and the ability of vessel walls to bind hormone facilitates transfer into the arterial blood (second step).

(3) Countercurrent transfer of hormones in the vasculature of the mesovarium and mesosalpinx makes retention possible and provides for a local mechanism of action of steroid hormones:

(i) by oviducal and uterine receptors which could influence the secretion and contractile activity of the oviduct and uterus;

(ii) by the theca and granulosa cells for regulation of their activity in a local feedback mechanism.

(4) Anastomoses between the ovarian and uterine arteries allow the transfer of a higher concentration of steroid hormones from the mesovarium area into the blood supplying the uterus and oviduct. On the one hand this mechanism and countercurrent exchange of hormones in the mesovarium area may protect the organism against a high concentration of steroids in the systemic blood supplying the central nervous system and other organs. On the other hand, they may locally allow considerably higher concentrations of steroids to be reached in target (i.e. genital) organs. This proposal is supported by the results of Magness \& Ford (1982) who observed that the concentration of oestradiol and oestrone was 3-4-fold higher in the uterine lymphatic effluent than in the systemic blood supplying the uterus, and of Peck $e t$ al. (1973) who found that total oestrogens were greater in the uterine tissues than in the systemic blood.

(5) The local passage of steroid hormones in the unbound state from the venous effluent into the arterial blood, near target organs, can significantly increase the quantity of free hormone able to interact with receptors.

(6) Countercurrent transfer of PGF-2 $\alpha$ in the mesometrial area, from the venous and lymphatic effluent into the arterial blood supplying the uterus (PGF-2 $\alpha$ back transfer), is very efficient during oestradiol-induced pseudopregnancy, early pregnancy (Day 18 of pregnancy) and during the luteal phase of the oestrous cycle. Consequently, it may considerably reduce peak prostaglandin concentrations during pulsatile release of PGF- $2 \alpha$ from the uterus. This may protect the corpus luteum against luteolysis because PGF- $2 \alpha$ is secreted during these periods by the uterus. We suggest that the dilatation of arterial vessels and the increase in blood flow through the mesometrial vasculature are the main factors increasing PGF-2 $\alpha$ back transfer. Moreover, many experiments indicate that oestradiol (catecholoestrogens) and adrenergic vasoconstrictor tone affect uterine blood flow (Ford, 1985), thus determining countercurrent transfer in the mesometrial area, while progesterone increases the ovarian blood flow in the mesovarial area.

(7) The endometrium, myometrium and the walls of arterial and venous vessels in the mesometrial area, as well as tissues surrounding the mesometrial vasculature, have different PGF- $2 \alpha$ uptake and retention ability which varies during the oestrous cycle and pregnancy. This forms the basis for PGF-2 $\alpha$ uptake and back transfer from the broad ligament vasculature into the uterus, and is involved in the mechanism of protection of the corpus luteum against luetolysis.

This work was supported by the Polish Academy of Sciences (Project RPBP 05.2). 


\section{References}

Adamowicz, S.S., Skipor, J., Grzegorzewski, W., Stefanczyk-Krzymowska, S. \& Krzymowski, T. (1989) The transfer of progesterone from the ovarian surface into venous blood of mesosalpinx vasculature of gilts. Proc. 2nd Int. Symp. Farm Anim. Endocrin., Smolenice Castle, pp. 1-2, abstr.

Baker, M.A. (1979) A brain-cooling system in mammals. Scient. Am. 240, 114-128.

Bazer, F.W. \& Thatcher, W.W. (1977) Theory of maternal recognition in swine based on estrogen controlled endocrine versus exocrine secretion of prostaglandin $F_{2 a}$ by the utcrine endometrium. Prostaglandins 14, $397-401$.

Del Campo, C.H. \& Ginther, O.J. (1972) Vascular anatomy of uterus and ovaries and unilateral luteolytic effect of the uterus: guinea pigs, rats, hamsters and rabbits. Am. J. vet. Res. 33, 256!-2578.

Del Campo, C.H. \& Ginther, O.J. (1973) Vascular anatomy of the uterus and ovaries and the unilateral lutcolytic effecl of the uterus: horses, sheep and swine. Am. J. vet. Res. 34, 305-316.

Dickson, W.M., Bosc, M.J. \& Locatelli, A. (1969) Efiect of estrogen and progesterone on uterine blood flow in castrate sows. Am. J. Physiol. 217, 1431-1434.

Doboszyńska, T., Janowicz, K., Stefanowski, T. \& Zamojska, D. (1980) Vascularization of the ovary in the period of estrus in the pig. Folia morph. (Warsz.) $39,37-53$.

Dynarowicz, J., Mortensen, A. \& Watkowski, T. (1988) Udzial receptorow adrenergicznych $w$ regulacji przeplywu krwi przez narzạd rodny świni w przebiegu cyklu rujowego. Pol. Archiw. Wet. 28, I15-127.

Einer-Jensen, N. (1974) Local transfer of ${ }^{133}$ xenon from the uterine horn to the ipsilateral ovary in the mouse, hamster and guinca-pig. $J$. Reprod. Fert. 40, 479-482.

Einer-Jensen, N. (1984) Slow binding of progesterone to plasma proteins. Acta pharmacol. toxicol. 55, 18-20.

Einer-Jensen, N. (1988) Countercurrent transfer in the ovarian pedicle and its physiological implications. Oxford Rev. Reprod. Biol. 10, 348-381.

Einer-Jensen, N. \& McCracken, J.A. (1981) The transfer of progesterone in the ovarian vascular pedicle of the sheep. Endocrinology 109, 685-690.

Einer-Jensen, N. \& Waites, G.M.H. (1977) Teslicular blood flow and a study of the testicular venous to arterial transfer of radioactive krypton and testosterone in the rhesus monkey. J. Physiol., Lond. 267, 332-336.

Ford, S.P. (1985) Maternal recognition of pregnancy in the ewe, cow and sow: vascular and immunological aspects. Theriogenology 23, 145-159.

Ford, S.P. \& Christenson, R.K. (1979) Blood flow to uteri of sows during the estrous cycle and early pregnancy: local effect of the conceptus on the uterine blood supply. Biol. Reprod. 21, 617-624.

Ford, S.P., Magness, R.R., Farley, D.B. \& Van Orden, D.E. (1982) Local and systemic effects of intrauterine estradiol-17 $\beta$ on luteal function of nonpregnant sows. J. Anim. Sci. 55, 657-664.

Ford, S.P., Reynolds, L.P., Farley, D.B., Bhatnagar, R.K. \& Van Orden, D.E. (1984) Interactions of ovarian steroids and periarterial $a_{1}-$ adrenergic receptors in altering uterine blood flow during the estrous cycle of gilts. Am. J. Obstet. Gynec. 150, 480-484.

Frank, M., Bazer, F.W., Thatcher, W.W. \& Wilcox, C.J. (1977) A study of prostaglandin $F_{20}$ as the luteolysin in swine. III Effects of estradiol valcrate on prosta. glandin $\mathbf{F}$, progestins, estrone and estradiol concentrations in the utero-ovarian vein of nonpregnant gilts. Prostaglandins 14, 1183-1196.

Free, N.J., Jaffe, R.A., Jain, S.K. \& Gomes, W.R. (1973) Testostcrone concentrating mechanism in the reproduclive organs of the male rat. Nature. New Biol. 244, 24-26.

Ginther, O.J. (1974) Internal regulation of physiological processes through local venoarterial pathways: a review. J. Anim. Sci. 39, 550-564.

Ginther, O.J. \& Del Campo, C.H. (1974) Vascular anatomy of the uterus and ovaries and the unilateral luteolytic effect of the uterus: cattle. Am. J. vet. Res. 35, 193-199.

Ginther, O.J., Garcia, M.C., Squires, E.L.\& Steffenhagen, W.P. (1972) Anatomy of vasculature of uterus and ovaries in the mare. Am. J. vet. Res. 33, 156I-1568.

Ginther, O.J., Del Campo, C.H. \& Rawlings, C.A. (1973) Vascular anatomy of the uterus and ovaries and the unilateral luteolytic effect of the uterus: a local venoarterial pathway between uterus and ovaries in sheep. Am. J. vet. Res. 34, 723-728.

Ginther, O.J., Mapletoft, R.J., Zimmerman, N., Meckly, P.E. \& Nuti, L. (1974) Local increase in testosteronc concentration in the testicular artery in rams. $J$. Anim. Sci. 38, 835-837.

Heap, R.B., Fleet, I.R. \& Hamon, M. (1985) Prostaglandin $F-2 \alpha$ is transferred from the uterus to the ovary in the sheep by lymphatic and blood vascular pathways. $J$. Reprod. Fert. 74, 645-656.

Hunter, R.H.F. \& Poyser, N.L. (1982) Uterine secretion of prostaglandin $F_{20}$ in anaesthetized pigs during the oestrous cycle and carly pregnancy. Reprod. Nutr. Develop. 22, 1013-1023.

Hunter, R.H.F., Cook, B. \& Poyser, N.L. (1983) Regulation of oviduct function in pigs by local transfer of ovarian steroids and prostaglandins: a mechanism to influence sperm transport. Eur. J. Obstet. Gynaec. Reprod. Biol. 14, 225-232.

Kotwica, J. (1980) Mechanism of prostaglandin F-2a penetration from the horn of the uterus to the ovaries in pigs. J. Reprod. Ferl. 59, 237-241.

Kotwica, J., Krzymowski, T., Stefanczyk, S., Nowicka, R., Debek, J., Czarnocki, J. \& Kuźnia, S. (1981) Steroid concentrating mechanism in the sows ovarian vascular pedicle. Adv. Physiol. Sci. 20, 149-152.

Kotwica, J., Williams, G.L. \& Marchello, M.J. (1982) Counter current transfer of testosterone by the ovarian pedicle of the cows: evidence for a rekationship 10 follicular steroidogenesis. Biol. Reprod. 27, 778-789.

Kotwica, J., Krzymowski, T., Stefanczyk, S., Koziorowski, M., Czarnocki, J. \& Ruszczyk, T. (1982/1983) A new route of prostaglandin $F_{20}$ transfer from the uterus into the ovary in swine. Anim. Reprod. Sci. 5, 303-309.

Koziorowski, M., Stefanczyk-Krzymowska, S., Okrasa, S., Czarnocki, J. \& Krzymowski, T. (1988) Radioactive prostaglandin $F_{20}$ absorption from the uterine lumen into the venous blood and its back transfer 
from the broad ligament vasculature during early pregnancy of the gilt. Proc. I/th Int. Congr. Anim. Reprod. \& A.l., Dublin, 2, 98, abstr.

Koziorowski, M., Stefanczyk-Krzymowska, S., Czarnocki, J.\& Krzymowski, T. (1989) Counter current transfer of oxytocin in area of cows broad ligament vasculature. Bull. Pol. Acad. Sci. (Biol. Sci.), 37, 109-1 16.

Krzymowski, T., Kotwica, J. \& Stefanczyk, S. (1979) Venous-arterial transfer of testosterone in the sow's ovarian pedicle. Proc. 2lst. World Vet. Congress, Moscow, 70, abstr.

Krzymowski, T., Kotwica, J. \& Stefanczyk, S. (1981a) Venous-arterial counter current transfer of $\left[{ }^{3} \mathrm{H}\right]$ testosterone in the vascular pedicle of the sow ovary. J. Reprod. Fert. 61, 317-323.

Krzymowski, T., Kotwica, J., Stefanczyk, S., Debek, J. \& Czamocki, J. (I98Ib) Venous-arterial counter current exchange of testosterone, estradiol and progesterone in sow's ovarian vascular pedicle. $A d v$. Physiol. Sci. 20, 153-157.

Krzymowski, T., Stefanczyk, S., Kotwica, J., Czarnocki, J., Glazer, T., Janowski, T. \& Chmiel, J. (1981/1982) ${ }^{3} \mathrm{H}$-oestradiol-17ß counter current transfer from ovarian vein into ovarian artery in cows. Anim. Reprod. Sci. 4, 199-206.

Krzymowski, T., Kotwica, J., Stefanczyk, S., Czarnocki, J. \& Debek, J. (1982a) A subovarian exchange mechanism for the counter current transfer of ovarian steroid hormones in the pig. J. Reprod. Fert. 65, 457-465.

Krzymowski, T., Kotwica, J., Stefanczyk, S., Debek, J. \& Czarnocki, J. (1982b) Stcroid transfer from the ovarian vein to the ovarian artery in the sow. $J$. Reprod. Fert. 65, 45I-456.

Krzymowski, T., Stefanczyk, S., Koziorowski, M., Czarnocki, J., Ruszczyk, T. \& Nowicka, R. (1982c) Role of mesosalpinx and oviduct vasculature in the counter-current transfer of steroid hormones into the ovary. Anim. Reprod. Sci. 5, 25-39.

Krzymowski, T., Czarnocki, J., Koziorowski, M., Kotwica, J. \& Stefanczyk-Krzymowska, S. (1986) Counter current transfer of ${ }^{3} \mathrm{H}-\mathrm{PGF}_{2 a}$ in the mesometrium: a possible mechanism for prevention of luteal regression. Anim. Reprod. Sci. 11, 259-272.

Krzymowski, T., Kotwica, J., Stefanczyk-Krzymowska, S., Czarnocki, J. \& Koziorowski, M. (1987) Prostaglandin $F_{2 a}$ back transfer from the mesometrium vasculature into the uterus of the gilt during early pregnancy and estrogen-induced pseudopregnancy. Anim. Reprod. Sci. 13, 199-210.

Krzymowski, T., Stefanczyk-Krzymowska, S. \& Koziorowski, M. (1989) Counter current transfer of $\mathrm{PGF}_{3 \alpha}$ in the mesometrial vessels as a mechanism for prevention of luteal regression in early pregnancy. Acra physiol. pol. 40, 23-34.

Lassen, N.A. \& Longley, J.B. (1961) Countercurrent exchange in vessels of renal medulla. Proc. Soc. exp. Biol. Med. 106, 743-748.

Lee, C.S. \& O'Shea, J.D. (1975) The extrinsic blood vessels of the ovary of the sheep. J. Morph. 148, 287-304.
Lundgren, O. (1967) Studies on blood flow distribution and counter-current exchange in the small intestine. Acta physiol. scand., Suppl. 303, 1-42.

Magness, R.R. \& Ford, S.P. (1982) Steroid concentration in uterine lymph and uterine arterial plasma of gilt during the estrous cycle and early pregnancy. Biol. Reprod. 27, 871-877.

Magness, R.R., Christenson, R.K. \& Ford, S.P. (1983) Ovarian blood flow throughout the estrous cycle and early pregnancy in sows. Biol. Reprod. 28, 1090-1096.

McCracken, J.A. \& Einer-Jensen, N. (1976) The counter current transfer of progesterone in the ovarian vascular pedicle. Proc. $5 \mathrm{th} \mathrm{lm}$. Congr. Endocrinol., Hamburg, 320, abstr. 775 .

McCracken, J.A., Carlson, J.C., Glew, M.E., Goding, J.R., Baird, D.T., Green, K. \& Samuelsson, B. (1972) Prostaglandin $F_{2 a}$ identified as a luteolytic hormone in the sheep. Nature, New Biol. 238, 129-134.

McCracken, J.A., Glew, M.E., Schramm, W. \& EinerJensen, $N$. (1984) The structure of steroids and their diffusion through blood vessels in a counter-current system. Steroids 43, 293-303.

Peck, E.J., Jr, Burgner, J. \& Clark, J.H. (1973) Estrophilic binding sites of the uterus. Relation to uptake and retention of estradiol in vitro. Biochemistry. NY 12, 4596-5601.

Schmidt-Nielsen, K. (1981) Counter-current system in animals. Scient. Am. 240, 100-106.

Schramm, W., Einer-Jensen, N. \& Schramm, G. (1986a) Direct venous-arterial transfer of ${ }^{125}$ ]-radiolabelled relaxin and thyroxin in the ovarian pedicle in sheep. J. Reprod. Fert. 77, 513-521.

Schramm, W., Einer-Jensen, N., Schramm, G. \& McCracken, J.A. (1986b) Local exchange of oxylocin from the ovarian vein to the ovarian arteries in the sheep. Biol. Reprod. 34, 671-680.

Staples, L.D., Fleet, I.R. \& Heap, R.B. (1982) Anatomy of utero-ovarian lymphatic network and the composition of afferent lymph in relation to the establishment of pregnancy in the sheep and goat. $J$. Reprod. Fert. 64, 409-420.

Stefanczyk, S. (1984) Mechanizm wiązania testosteronu przez obszar szypuly naczyniowej jajnika i macicy. (Mechanism of binding of testosterone by ovarian vascular pedicle and uterus). Post. Nauk. Rol. 309, 181-189.

Thatcher, W.W., Bazer, F.W., Sharp, D.C. \& Roberts, R.M. (1986) Interrelationship between uterus and conceptus to maintain corpus luteum function in early pregnancy in sheep, cattle, pigs and horses. $J$. Anim. Sci. 62 (Suppl. 2), 25-46.

Waites, G.M.H. \& Moule, G.R. (1961) Relation of vascular heat exchange to temperature regulation in the testis of the ram. J. Reprod. Fert. 2, 213-224.

Walsh, S.W., Yutrzenka, C.J. \& Davis, J.S. (1979) Local steroid concentrating mechanism in reproductive vasculature of the ewe. Biol. Reprod. 20, I167-1171. 